\author{
(online) $=$ ISSN $2285-3642$ \\ ISSN-L = 2285 - 3642 \\ Journal of Economic Development, Environment and People \\ Volume 3, Issue 1, 2014 \\ URL: http://jedep.spiruharet.ro \\ e-mail: office jedep@spiruharet.ro
}

\title{
Estimation and valuation in accounting
}

\author{
Professor Cicilia IONESCU, $\mathrm{PhD}^{1}$, Associated Professor Floarea GEORGESCU, $\mathrm{PhD}^{2}$ \\ Spiru Haret University, str. Fabricii, no. 46 G, sect. 6, Bucharest ${ }^{1}$ \\ ciciliaionescu@yahoo.com \\ Spiru Haret University, str. Fabricii, no. 46 G, sect. 6, Bucharest ${ }^{2}$ \\ georgescuflori@yahoo.com
}

\begin{abstract}
The relationships of the enterprise with the external environment give rise to a range of informational needs. Satisfying those needs requires the production of coherent, comparable, relevant and reliable information included into the individual or consolidated financial statements. International Financial Reporting Standards IAS / IFRS aim to ensure the comparability and relevance of the accounting information, providing, among other things, details about the issue of accounting estimates and changes in accounting estimates. Valuation is a process continually used, in order to assign values to the elements that are to be recognised in the financial statements. Most of the times, the values reflected in the books are clear, they are recorded in the contracts with third parties, in the supporting documents, etc.

However, the uncertainties in which a reporting entity operates determines that, sometimes, the assigned or values attributable to some items composing the financial statements be determined by use estimates.
\end{abstract}

Keywords: valuation, estimation, valuation basis, historical cost, fair value, change of estimation, financial statements

\section{JEL Codes: M41}

\section{Introduction}

In addressing this issue, the whole approach is based on the discrepancy between the views of professional accountants and those of the theorists in the field. This discrepancy increased with the generalization of the theoretical research, generating a lack of intelligibility for practitioners. Our opinion is that an alienation of theory from practice and vice versa only leads to a limitation of satisfying the need of financial-accounting information of the users. Therefore, we believe that research should be directed towards associating the theoretical research information to the information provided by the reality of the economic environment in which the activities but also the evolutionary behaviour of users develop.

Specialists consider that the beginning of the financial crisis from 2008 in USA represents the most serious convulsion of the international finances since the Great Depression of 1929-1933. The effects of the actual crisis spread, beyond the financial sphere, into the world economy as a whole, affecting the economic growth and the labour market and generating a series of related effects, with incidental or 


\author{
(online) $=$ ISSN $2285-3642$ \\ ISSN-L = 2285-3642 \\ Journal of Economic Development, Environment and People \\ Volume 3, Issue 1, 2014 \\ URL: $\underline{\text { http://jedep.spiruharet.ro }}$ \\ e-mail: office jedep@spiruharet.ro
}

medium or long term implications regarding the structure of the global financial system and its interface with the real economy as a result of the universality of the economic-financial crisis.

The transfer of the adverse effects of the crisis from one country to another is based on the increasing interdependency of the national economies within the process of intensifying the globalization of markets, including the financial ones. If the financial system of a country crashes or is paralyzed, then its economy can no longer function normally given its multiple interference with national and international financial systems.

In order to control the adverse effects of the financial crisis, it is absolutely necessary to know in depth the causes that generated it and maintain it and to instrument organic policies and means connected to local, regional, national and international levels.

Placing the value at the centre of the bodies developing the accounting standards' reasoning basis can induce the assumption that information is transmitted effectively within the market, generating a price of the shares that represents a true reflection of the performance of that entity, while every serious economic crisis brings significant doubt on the same association. We can say that we are dealing with a crisis evaluation.

... from many points of view, the current financial crisis is connected to valuation (Noyer, 2008).

The ability to achieve a proper valuation is the key to financial activity, because in order to buy or sell a financial instrument is important, objectively necessary, to know its value. Also, after the purchase of a financial asset or the contraction of a financial liability, valuation is the key to success in the risk management implied by this element, but also in reporting the created value to shareholders of the company. The credit crisis produced in 2007 was the cause for the loss of jobs for many CFOs, but also for the bankruptcy or sale of many financial institutions. Over time, two major problems have emerged as being those that led to this crisis. One of these is represented by the models used to determine the fair value, too narrow models to connect the changes emerged in the real estate price to the values of those financial instruments whose active support they were, by a more or less complex structure. The second problem is the lack of providing some information that has to be known by some investors, a lack that would have stopped even the best valuation technique from generating a significant level of accuracy. (Deventer, 2008)

\title{
2. Fair value, alternative of the historical price
}

Currently, we are witnessing a reformulation of the accounting model upon the value, which consists in reconsidering the fundamental principles of valuation. Accounting evolves form the principle of the historical cost to that of the current value.

Questioning the valuation of the historical costs is not a new issue. The inflationary times, characterized by significant price increases, have shown that historical cost accounting provides a distorted picture of reality: both the balance sheet items and the expenses with amortization and stocks from income 


\author{
(online) = ISSN $2285-3642$ \\ ISSN-L = 2285-3642 \\ Journal of Economic Development, Environment and People \\ Volume 3, Issue 1, 2014 \\ URL: $\underline{\text { http://jedep.spiruharet.ro }}$ \\ e-mail: office jedep@spiruharet.ro
}

and loss accounts are underestimated. In these conditions, the result is overrated and its distribution leads to allocations from the entity's capital.

Searching for alternative values for the historical cost has as a purpose the improvement of the quality of the financial statements and the attempt to use reliable and relevant information for all the users.

Using the fair value could contribute significantly to improving the financial information increasing the interest of the users, but it can also be highly subjective, allowing for manipulation by those who estimate it and, consequently, for distortions of the financial statements. This phenomenon may occur when the use of the fair value is not accompanied by adequate disclosure of information in annotations.

The use of fair value is a widely debated topic at present, the major financial institutions recognizing, in the financial statements, losses of several billion dollars, mostly from the use of the fair value as valuation basis. The main criticism against it is that it requires the inclusion in the result of some "virtual" elements arising from the market development, leading to a result characterised by a high volatility. This does not mean, however, abandoning the fair value as a valuation basis. The purpose assigned to fair value accounting and market-based valuations does not seem to be exaggerated if we integrate it into the picture that presents the characteristics of the financial markets in an emerging world.

Switching from a historical cost-based accounting to one based on fair values has been catalogued as a conceptual revolution in accounting. The objective of fair value-based accounting is to reflect market values into the financial statements, with the all risks related to the fact that the estimation of this value remains a subjective process, especially when it is made in the absence of a market, which involves not only professional judgment but also the possibility of manipulation by the person whom performs it.

For the first time, the fair value was mentioned in the Romanian accounting regulations in 2001 , then in 2002, when it was chosen the connection of the Romanian accounting to international accounting standards and, subsidiary, to the European ones, which were not updated in the context of the international convergence. Today, by waiving the mentioned rules and the adoption of the (updated) European directives, we remain in the spirit of international accounting standards and therefore the acceptance of fair value. The current accounting regulations accept the fair value valuation only for the revaluation of fixed assets, for asset swaps, for free of charge received goods, for financial instruments from the consolidated financial statements. Thus, it was chosen a mixed system based on historical cost and fair value, in which the valuation at the historical cost prevails.

The desire of the international setters is to broaden the practice of fair value valuation of all balance sheet items. The controversies regarding this have not hesitated to appear, being considered that fair value presents a risk of results' manipulation, being in fact an accounting estimate that may lead to creative accounting-like behaviours. Therefore, broadening the application of fair value valuation does not enjoy the greatest support from the accounting profession because "in all the environments, not just in Europe, not only in the French banks, there is a resistance to fair value". (Gelard Gil, IASB member) 


\author{
(online) $=$ ISSN $2285-3642$ \\ ISSN-L = 2285-3642 \\ Journal of Economic Development, Environment and People \\ Volume 3, Issue 1, 2014 \\ URL: $\underline{\text { http://jedep.spiruharet.ro }}$ \\ e-mail: office jedep@spiruharet.ro
}

\title{
3. Accounting estimates, necessity and opportunity
}

The relationships of the enterprise with the environment give rise to a series of informational need. Satisfying those needs requires the production of coherent, comparable, relevant and reliable information included into the individual or consolidated financial statements. International Financial Reporting Standards IAS / IFRS aim to ensure the comparability and relevance of the accounting information, providing, among other things, details about the issue of accounting estimates and changes in accounting estimates.

The frequently asked question, both by the formulators of accounts and by the users of accounting information, more or less competent, is: Why should we estimate some information from the financial statements?

The answer to such a question varies, on the one hand, depending on the purpose of each user of financial information and, on the other hand, to determine the monetary valuescorresponding to the selected valuation bases for the elements that make up the financial statements. Related to this latter aspect, we note that the International Accounting Standards refer to the concept of accounting policies as specific principles, bases, conventions, rules and practices applied by an entity in the drafting and presentation of the financial statements. Therefore, the valuation bases are accounting policies that significantly affect the analysis of the balance sheet, profit and loss account, cash flow panel, the panel of changes in equity and notes to the financial statements.

In order to develop an efficient information system based on estimation techniques, we need to know first which are the elements of financial statements that have to be evaluated by resorting in order to estimates, leading to obtain the current value in the financial statements.

For realizing this process it is required the choice of a convention, valuation bases identified by the IASB, through its conceptual Framework, such as historical cost, current cost, feasible value (of settlement), the updated value.

Although the most common valuation basis adopted by businesses in the financial statements is the historical cost, the IASB Board does not impose a specific base. Thus, the entities use different valuation bases uniquely or in various combinations. In Romania the historical cost is used in most cases, a situation driven by the Romanian companies focus on verifiability of the information obtained my means of this Convention.

Thus, obtaining a current value of an asset in the financial statements will also depend on the circumstances in which both the entity and the asset are. The existence of such circumstances allows the entity to determine, in fact, some estimated values at a certain time. The desire is that these values represent the best estimates, given the circumstances.

The estimates are judgments based on assumptions and future projections regarding items that cannot be accurately assessed at present. In the accounting practice, we can use estimates especially for: 


\author{
(online) = ISSN $2285-3642$ \\ ISSN-L = 2285 - 3642 \\ Journal of Economic Development, Environment and People \\ Volume 3, Issue 1, 2014 \\ URL: $\underline{\text { http://jedep.spiruharet.ro }}$ \\ e-mail: office jedep@spiruharet.ro
}

- determining the amount of the depreciation provisions of debts and stocks in order of bringing them to the estimated net realizable value;

- determining the amount of provisions for risks and expenses;

- determining the amount of provisions for satisfying contracted securities;

- determining the useful lives of intangible and tangible assets;

- determining the residual value of an asset;

- determining losses from construction contracts in progress, etc.

Most of the times, the effect of accounting estimates takes the form of revenues and expenditures, which means they affect the profit and loss account both of the financial year in which the estimate takes place and of the future financial years, if the estimated item unfolds over several periods.

\title{
4. Accounting estimates regarding inventories
}

According to IAS 2 "Inventories", the valuation of stocks at balance is realized at the lower value between the cost and the net realizable value, representing the estimated selling price that could be obtained in the ordinary course of business, less the estimated costs of completion and necessary costs of sale. In this case historical cost valuation basis and realisable value valuation basis combine.

At the financial year's end, the inventories in storage are inventoried, during which time the possibilities of recovering the cost of these stocks in the following period is analysed. Given that the estimated value is recovered, meaning that the price at which they could be recovered is less than the cost, the inventories should be valued at the lower value between the cost and the net realizable value.

The depreciation of inventories cost may be partial or total, due to their damage through obsolescence or if their selling price has suffered a reduction. At the same time, the cost of inventories may not be covered, given the fact that the estimated cost necessary to achieve the sale has increased.

The balance items should be reflected in the annual financial statements at a value lower than the value that can be obtained through their sale or use, which means the reduction of inventories value below the cost, to the net realizable value, that is the estimated selling price that could be obtained during the ordinary course of business, less estimated costs of completion and necessary costs of sale. Any recognized depreciation shall be treated as an expense of the period and not as an expense of the inventory cost.

Therefore, the inventory cost is not recoverable if the inventory is in one of the following situations is damaged, is entirely or partially obsolete, the selling price decreased or the estimated cost of completion and sale of the product has increased.

\section{Example 1:}

A company purchased imported goods that require packaging and labelling works. The incurred expenses are shown in the following table: 


\author{
(online) $=$ ISSN $2285-3642$ \\ ISSN-L = 2285 - 3642 \\ Journal of Economic Development, Environment and People \\ Volume 3, Issue 1, 2014 \\ URL: http://jedep.spiruharet.ro \\ e-mail: office jedep@spiruharet.ro
}

- m.u. -
\begin{tabular}{|l|l|}
\hline Purchase price invoiced by the supplier & $62,500.00$ \\
\hline Customs duties paid (10\%) & $6,250.00$ \\
\hline Customs fee (0.5\%) & 312.50 \\
\hline VAT paid in customs (24\%) & $16,575.00$ \\
\hline Transport costs along the country & $8,925.00$ \\
\hline Manipulation expenses & 250.00 \\
\hline Expenses for checking the quality of goods & $1,750.00$ \\
\hline Insurance premium for the goods & $2,250.00$ \\
\hline Commercial discount granted by supplier & $1,500.00$ \\
\hline Exchange difference & 250.00 \\
\hline
\end{tabular}

The enterprise estimates that the goods will be sold at the price of $150,000 \mathrm{~m}$.u. The sale will require sale preparation costs of 65,000 m.u., effective selling costs of 20,000 m.u.

- m.u. -

\begin{tabular}{|l|l|}
\hline Selling price & 150,000 \\
\hline (-) Sale preparation costs & 65,000 \\
\hline (-) Effective selling costs & 20,000 \\
\hline (=) NET REALISABLE VALUE & $\mathbf{6 5 , 0 0 0}$ \\
\hline
\end{tabular}

In compliance with IAS 2, in our example the minimum between $69,062.50$ m.u. and 65,000 m.u. is $65,000 \mathrm{~m} . \mathrm{u}$. Therefore, this is the value of stocks that will be recognized in the financial statements.

\title{
5. Accounting estimates regarding tangible assets
}

\section{Estimating depreciation}

International accounting standard IAS 16 "Property, Plant and Equipment" provides that the depreciable amount of a tangible asset should be systematically (meaning that depreciation must be based on a method chosen when accounting the asset) allocated throughout its useful life. The depreciation method chosen should reflect the pattern of consumption of economic benefits expected as a result of using the asset, and must be applied consistently throughout the usage period of that asset.

The calculation of a tangible assets depreciation implies an whole number of reasonable estimates both for determining its useful life, its residual value but also the initial costs for the asset decommissioning and site restoration (for long-term assets), in accordance with allowed alternative treatment in IAS 37 "Provisions, Contingent Liabilities and Contingent Assets". 


\author{
(online) $=$ ISSN $2285-3642$ \\ ISSN-L = $2285-3642$ \\ Journal of Economic Development, Environment and People \\ Volume 3, Issue 1, 2014 \\ URL: $\underline{\text { http://jedep.spiruharet.ro }}$ \\ e-mail: office jedep@spiruharet.ro
}

A specific reasoning applies when estimating the useful life of the assets. This is based on both the professional judgment (based on the entity's experience in using similar assets) and updated cash flows to be generated by that asset. Therefore, determining the duration of the utility is actually the utility expected by the in relation to the asset, considering many factors such as:

- estimated level of the asset usage, given the expected capacity or physical output of the asset;

- expected physical wear and tear of the asset, which, in its turn, depends on the operating conditions such as the number of exchanges in which the repair and maintenance program performed by the enterprise is used, the maintenance and asset conservation method, etc.;

- the obsolescence that asset is subjected as a result of changes in the structure of market demand for goods and services provided, to which the asset subject to depreciation is part of;

- the legal limits regarding the possibility of using the asset (where goods are the subject of a finance lease).

\title{
Example 2:
}

In order to achieve a contract regarding the provision of 360,000 pieces in three years, a company has manufactured a special machine whose production cost is $180,000 \mathrm{~m} . \mathrm{u}$.

The estimated value of the production and the pieces delivery schedule were fixed by agreement with the client, as follows:

- in year 1: 72.000 pieces

- in year 2: 90.000 pieces

- in year 3: 198.000 pieces

The machine is taken out of operation at the end of the third year.

The enterprise does not wish to apply the classical methods of depreciation (linear or degressive, for example) because they do not lead to a real rate of depreciation of that machinery. Therefore, the company decided that depreciation should be based on the quantities produced, as follows:

- in year 1: $180.000 \times 72.000 / 360.000=36.000 \mathrm{~m} . \mathrm{u}$.

- in year 2: $180.000 \times 90.000 / 360.000=45.000$ m.u.

- in year 3: $180.000 \times 198.000 / 360.000=\underline{99.000 ~ m . u}$. 180.000 m.u.

The estimation of the residual value arises from the very definition of IAS 16, and it represents the amount that the enterprise expects to obtain by reselling the property at the end of usage period, amount of which the value of the transfer expenses is reduced. 


\author{
(online) = ISSN $2285-3642$ \\ ISSN-L = 2285 - 3642 \\ Journal of Economic Development, Environment and People \\ Volume 3, Issue 1, 2014 \\ URL: $\underline{\text { http://jedep.spiruharet.ro }}$ \\ e-mail: office jedep@spiruharet.ro
}

\title{
Estimating the impairment of assets
}

If an asset is considered depreciated when its useful life ended, an asset is considered impaired when the input value, adjusted with the accumulated depreciation, is greater than the recoverable amount (IAS 36 Impairment of Assets).

To be able to assess the recoverable amount of an asset we must, first of all, to be able to estimate the net selling price and the usage value of that asset, and the maximum of the two values will represent the recoverable amount.

We should specify the fact that not always the both landmarks must be evaluated. If the selling price is higher than the net accounting value. then the asset is not considered impaired. In these circumstances, the amount of utility is no longer necessary to be determined.

a. The best estimate of the selling price of an asset is that related to a sales contract, in which the price is objectively determined and adjusted depending on the additional costs attributable to the disposal. When such a contract of sale does not exist, then the best estimate of the selling price is the market price (the current auction price, the price of the most recent transaction), except the costs of disposal of property (legal fees, postage costs, costs regarding the asset movement, additional costs of sale, etc.). If the asset does not have an active market and no sales contract with an objectively determined price, then it is taken into consideration the prices of the recent transactions for similar assets, from the same economic sector.

b. Regarding the valuation of the utility value, this is more complicated, as it requires overcoming two stages:

Stage 1: estimating future cash flows arising from the continued use of the asset and the latest output (residual value), and

Stage 2: updating the future cash flows (associated with the use of the asset) using appropriate updating rates.

In order to estimate the future cash flows associated with the use of the asset we must take into account several variables, namely:

- management's best estimates based on the set of existing economic conditions throughout the remaining useful life of the asset;

- financial projections and forecasts approved by management over a period of 5 or more than 5 years, if applicable;

- exploration of previous forecasts for the coming years, based on a constant increase / decrease rate (not greater than of the branch, country or geographical area corresponding to the business activity);

- the possibility that the asset be used or not continuously;

- the existence of related cash inflows associated with the usage of the asset and attributable to this on reasonable or practical basis;

- the existence of cash flows when selling the asset, at the end of its useful life. 


\author{
(online) $=$ ISSN $2285-3642$ \\ ISSN-L = 2285-3642 \\ Journal of Economic Development, Environment and People \\ Volume 3, Issue 1, 2014 \\ URL: $\underline{\text { http://jedep.spiruharet.ro }}$ \\ e-mail: office jedep@spiruharet.ro
}

In estimating future cash flows, we should not include the effects of any future possible restructuring, not yet committed, or future capital expenditures, which will increase the initial asset performance or cash flows generated by the income tax.

If the involvement of foreign currency flows is also forecasted, then the associated cash flows will be changed at the exchange rate at the balance sheet date, according to IAS 21 "The Effects of Changes in Foreign Exchange Rates".

Regarding the update of future cash flows, we specify that after estimating the value of future cash flows, this it will be updated at a update rate (rates) (to cover the specific risks of the market - monetary risk, price risk, country risk) prior to the taxation of income that will reflect the time value of specific money and risks. Usually, the update rates are rates of return on investment that would generate the same amount of cash flows, during the same time interval and the same specific risks involved. They can be assimilated with the default rates on market for transactions with similar assets or the average weighted interest rate (capital cost rate) for a company listed that has a single asset (or portfolio of assets) similar in potential and risks to the analysed asset.

\title{
6. Accounting estimates related to provisions
}

According to IAS 37 Provisions, Contingent Liabilities and Contingent Assets, the value of a provision shown in the financial statements should be given by the best estimate of the required costs in order to settle the present obligation, at the balance sheet date. When the time-value effect of money is considerable, the provision is formed at the update value of the expenditures expected to be required in order to settle the obligation. To estimate these costs, the existence of similar transactions and, in some cases, the opinions of independent experts will be taken into account.

Presentation of debts clients (doubtful clients) on the balance sheet, when claims are likely not to be recovered entirely, will be realised at the realizable value by correcting the input value with the value losses caused by estimating their degree of non-recovery.

\section{Changes of accounting estimates}

Estimates represent approximate sizes determined by certain circumstances existing at a certain moment. National and international accounting regulations allow and at the same time require the review of any estimates when changes on the initial circumstances on which that estimate was based on or as a result of new information or a new experience or subsequent developments occur.

The effect of a change in accounting estimates should be included in determining the net result during:

a) the financial year of change, if the change affects only the financial year in question, or 


\author{
(online) $=$ ISSN $2285-3642$ \\ ISSN-L = $2285-3642$ \\ Journal of Economic Development, Environment and People \\ Volume 3, Issue 1, 2014 \\ URL: $\underline{\text { http://jedep.spiruharet.ro }}$ \\ e-mail: office jedep@spiruharet.ro
}

b) the financial year of change and future financial years, if the change affects both the current financial year and the next.

Estimates are periodically reviewed and modified if necessary. The question is whether such a change calls into question the results of previous financial years. The answer is no. Indeed, the international accounting standard IAS 8 but also the current Romanian accounting regulations stipulate that the influence of a change in accounting estimate should affect the net result of the current financial year and, if appropriate, those of the following years. The results of the previous financial years should not be changed.

\title{
Example 3:
}

In the financial year N-1, to account for the risk of insolvency of a customer, company ALFA has made a provision estimated in the amount of 55,000 m.u. At the end of financial year $\mathrm{N}$, it is estimated that the situation of this client improved, so that a provision of 30,000 m.u. should be enough. This change in estimate is entirely found in the result for the financial year $\mathrm{N}$. The expenses for the financial year $\mathrm{N}-1$, according to the rules, are not affected. The adjustment of the provision will only affect the financial year $\mathrm{N}$, in which will be accounted as follows:

December $31 / \mathrm{N}$

Provisions for clients impairment

$=\quad$ Reversal of provisions

25,000 m.u.

\section{Example 4:}

Company BETA possesses an equipment purchased at the price of 60,000 m.u., on April $1 / \mathrm{N}-3$. The estimated duration of use at the time of purchase was 10 years. The following impairments were applied:

- in the financial year N-3: $(60,000 / 10) \times 9 / 12=4,500$ u.m.

- in the financial year N-2: 60,000/10=6,000 u.m.

- in the financial year N-1: $60,000 / 10=6,000$ u.m. 16,500 u.m.

Taking into account a more intensive use of the equipment, at the end of the financial year $\mathrm{N}$ it is estimated that the useful life will be reliably of eight years. Net book value at 31 December/N-1, of 43,500 m.u. $(60,000-16,500=43,500)$ must be depreciated, therefore, during the remaining useful life of 5.25 years ( 5 years and 3 months or 5.25 ), where the following depreciation expenses appear:

- in the financial year $\mathrm{N}: \quad 43,500 / 5.25=8,285.714$, instead of 6,000

- in the financial year $\mathrm{N}+1: 43,500 / 5.25=8,285.714$, instead of 6,000

- in the financial year $N+2: 43,500 / 5.25=8,285.714$, instead of 6,000

- in the financial year $N+3: 43,500 / 5.25=8,285.714$, instead of 6,000 


\author{
(online) $=$ ISSN $2285-3642$ \\ ISSN-L = $2285-3642$ \\ Journal of Economic Development, Environment and People \\ Volume 3, Issue 1, 2014 \\ URL: http://jedep.spiruharet.ro \\ e-mail: office jedep@spiruharet.ro
}

- in the financial year $\mathrm{N}+4: 43,500 / 5.25=8,285.714$, instead of 6,000

- in the financial year $\mathrm{N}+5:(43,500 / 5.25) \times 3 / 12=2,071.428$, instead of 6,000

- in the financial year $\mathrm{N}+6$ :

0 , instead of 6,000

- in the financial year $\mathrm{N}+7$ :

0 , instead of 6,000

We can notice that the impairments prior to the financial year $\mathrm{N}$ have not been corrected; instead, the impairments of the financial year $\mathrm{N}$ and the future ones have been corrected.

A change in accounting estimate is not, by itself, an extraordinary item. The incidence of change is, in fact, an element of the same category (ordinary or extraordinary) as the element whose change was modified.

\title{
Example 3 (continuation):
}

If the depreciation of claim against the client in question was initially considered as an ordinary activity, the resumption of the provision is also an ordinary activity.

When a change has a significant incidence on the current financial year or is likely to have it on future financial years, its nature and size should be mentioned in the financial statements. If the size in question cannot be quantified, this aspect must be reported.

In many cases, it is difficult to distinguish between changes in methods and changes in estimates. The IAS 8 standard clearly outlines this doubt, considering that the amendment shall be treated as a change in estimate.

\section{Conclusion}

As a conclusion to those presented above, we consider that the issue of estimates, as a work and valuation procedure, should be systematically addressed by each entity, taking as a starting point defining the objective of financial statements, their structure but also the qualitative requirements, which must be met by the information contained in financial reporting.

\section{References:}

[1] Bogliolo, F., La creation de valeur, Editiones D'Organisation, Paris, 2000

[2] Deaconu, A., Valoarea justă concept contabil, Editura Economică, București, 2009

[3] Feleagă, N., Malciu, L., Recunoaștere, evaluare și estimare în contabilitatea internațională, Editura CECCAR, București, 2004

[4] Ionescu Cicilia, Sisteme Contabile Moderne, Editura Fundaţiei România de Mâine, Bucureşti, 2005

[5] Ionescu Cicilia, Informarea financiară în contextul internaţionalizării contabilităţii, Editura Economică, Bucureşti, 2003

[6] Ionescu Cicilia, Contabilitatea crizei sau criza contabilității, Editura Universitară, București, 2012 


\author{
(online) $=$ ISSN $2285-3642$ \\ ISSN-L = 2285 - 3642 \\ Journal of Economic Development, Environment and People \\ Volume 3, Issue 1, 2014 \\ URL: http://jedep.spiruharet.ro \\ e-mail: office jedep@spiruharet.ro
}

[7] Cicilia Ionescu, Optimizarea deciziei financiare la nivelul firmei, Academia Română, Centrul de Cercetări financiare şi Monetare „Victor Slăvescu”, Editura Academiei Române, Bucureşti, 2004

[8] Matis, D., Mustață, R., De la costul istoric la valoarea justă, Revista Finanțe Publice și Contabiltate, nr 11-12, București, 2004

[9] Nica, D., Ionescu, C., Balu M, Dobrin, M., Ionescu, E., Evaluarea întreprinderii, Editura Fundației România de Mâine, București, 2007

[10] Șerban, C., Evaluation and Estimation in Accounting Concept Evolution, 200

[11] Hennie van Greuning, International Financial Reporting Standards, A practical guide, Editura Irecson, 2007 